\title{
POTENSI IKAN AIR TAWAR BUDIDAYA SEBAGAI BAHAN BAKU PRODUK NUTRASEUTIKAL BERBASIS SERUM ALBUMIN IKAN
}

\section{The Potency of Aquaculture Freshwater Fishes as a Raw Material for Fish Serum Albumin Based Nutraceutical Products}

\author{
Rini Susilowati ${ }^{1^{*}}$, Hedi Indra Januar ${ }^{1}$, Diini Fithriani ${ }^{1}$, dan Ekowati Chasanah ${ }^{1}$ \\ ${ }^{1}$ Balai Besar Penelitian dan Pengembangan Pengolahan Produk dan Bioteknologi Kelautan dan Perikanan. \\ JI. K.S. Tubun Petamburan VI, Jakarta Pusat, Indonesia \\ * Korespondensi Penulis: rinicas@yahoo.com
}

Diterima: 25 Maret 2015; Disetujui: 15 Mei 2015

\begin{abstract}
ABSTRAK
Nutraseutikal berbasis Fish Serum Albumin (FSA) adalah produk komersial yang berasal dari sumber perairan. Namun, oleh karena produk ini secara umum diproduksi dari ikan gabus (Channa striata) di alam, pasokan bahan baku dapat menjadi masalah pada produksi yang berkesinambungan. Penelitian ini telah dilakukan dengan menganalisis kandungan FSA dari 17 ikan air tawar budidaya, untuk mendapatkan bahan baku alternatif bagi produk nutraseutikal berbasis FSA. 3-10 individu ikan air tawar (150-500 g) dari jenis ordo Perciformes, Anguilliformes, Cypriniformes, Osteoglossiformes, dan Siluriformes telah diambil secara acak dari lokasi budidaya ikan di Bogor dan Cianjur (Jawa Barat). Ekstraksi protein larut air dilakukan menggunakan Ultra Turax homogeniser dengan pelarut akuabides. Analisis FSA telah dilakukan menggunakan High Performance Liquid Chromatography (HPLC). Hasil dari penelitian menunjukkan bahwa kadar FSA dari 17 ekstrak air dari ikan berada pada rentang 42,51 to $215,57 \mathrm{mg} / \mathrm{g}$, dengan kadar FSAikan gabus pembanding adalah 107,28 $\pm 3,2 \mathrm{mg} / \mathrm{g}$. Konsentrasi FSA tertinggi ditemukan sebesar 215,57 $\pm 52,84 \mathrm{mg} / \mathrm{g}$ dari ekstrak air ikan gurame (Osphronemus gouramy). Analisis lebih lanjut terhadap komposisi asam amino menggunakan Gas Chromatography - Flame Ionization Detector (GC-FID) menemukan bahwa ekstrak air ikan gabus memiliki konsentrasi asam amino esensial dan non-esensial yang lebih tinggi dibandingkan dengan ikan gurame. Hal ini menunjukkan banyaknya protein lain selain FSA pada ekstrak air ikan gabus dibandingkan ikan gurame. Berdasarkan hasil ini, ekstrak air ikan gurame memiliki konsentrasi FSA yang lebih besar dan relatif lebih murni dibandingkan ekstrak air ikan gabus, sehingga merupakan alternatif yang prospektif sebagai bahan baku untuk produk nutraseutikal berbasis FSA.
\end{abstract}

KATA KUNCl: $\quad$ serum albumin ikan, nutrasetikal, budidaya, ikan air tawar

\section{ABSTRACT}

Fish Serum Albumin (FSA) based nutraceutical is a commercial product from aquatic resources. However, as the product is usually developed from wild freshwater snakehead fish (Channa striata), raw material supply may become a problem at continuous production. This research had been done to analyze FSA level in 17 aquaculture freshwater fishes, aimed to find an alternative of raw material sources in FSA based neutrasetical products. 3-10 individuals of freshwater fishes (150$500 \mathrm{~g})$ from Perciformes, Anguilliformes, Cypriniformes, Osteoglossiformes, and Siluriformes ordo were taken randomly from Bogor and Cianjur (West Java) aquaculture fields. Aqueous protein extraction was performed by Ultra Turax homogeniser with aquabidest solvent. Analysis of albumin content had been done by High Performance Liquid Chromatography (HPLC). The results showed that FSA level in aqueous extracts of observed fishes were 42.51 to $215.57 \mathrm{mg} / \mathrm{g}$, while FSA in aqueous snakehead fish extract was $107.28 \pm 3.2 \mathrm{mg} / \mathrm{g}$. The highest FSA concentration was $215,57 \pm 52,84 \mathrm{mg} / \mathrm{g}$ from giant gouramy (Osphronemus gouramy). Further analysis at amino acid composition by Gas Chromatography - Flame Ionization Detector (GC-FID) showed that the aqueous extract of snakehead fish composed higher concentration of essential and non-essential amino acids than that of giant gouramy. This may indicate that there were other protein than FSA in the aqueous extract of snakehead compared to that of giant gouramy. Based on this study, the aqueous extract of giant gouramy contains higher level and purity of FSA compared to the aqueous extract of snakehead fish, and therefore is a prospective alternative as a raw material for FSA based nutraceutical products.

KEYWORDS: fish serum albumin, nutraceutical, aquaculture, freshwater fish 


\section{PENDAHULUAN}

Serum albumin merupakan suatu jenis protein yang penting dalam sistem metabolisme ikan. Protein Fish Serum Albumin (FSA) memiliki fungsi untuk membantu transportasi metabolit tubuh (asam lemak, hormon, bilirubin), mengatur sistem regulasi tekanan osmotik koloid darah dan proses osmoregulasi pada tubuh ikan, serta sebagai penyaring cairan dalam jaringan tubuh (De Smet et al., 1998; Baker, 2002; Andreeva, 2011; Kovyrshina \& Rudneva, 2012). Protein ini memiliki karakteristik khas dengan muatan negatif dengan $\mathrm{pl}=5,67$ dan bobot molekul relatif rendah 66000 kD (De Smet et al., 1998; Baker, 2002). FSA ini memiliki ciri khas yang mirip dengan Human Serum Albumin (HSA). Ikan Channa gachua dan Channa gariepinus (lele dari Afrika) memiliki albumin like protein berupa monomer, $70 \mathrm{kDa}$, selaras dengan Human Serum Abumin (HSA) pada struktur sekundernya (Hasnain et al., 2004).

Selain itu, FSA juga memiliki bioaktivitas yang berguna bagi kebutuhan farmakologis dan telah menjadi suatu produk nutraseutikal yang komersial. Produk nutraseutikal berbasis FSA yang umumnya berasal dari ikan gabus (Channa striata) telah diproduksi oleh beberapa Usaha Kecil dan Menengah (UKM) di Indonesia dan telah beredar di pasaran. Ikan gabus telah dikenal memiliki manfaat yang sangat besar pada kesehatan di wilayah Asia Tenggara, termasuk Indonesia. Secara tradisi, ikan gabus telah dikenal sebagai penyembuh luka, penghilang rasa sakit, inhibitor ACE, anti depresi, dan penyakit degeneratif saraf (Shafri \& Manan, 2012). Ekstrak ikan gabus yang mengandung FSA telah menjadi produk yang diperlukan pada beberapa rumah sakit (RS) sebagai pendamping pengobatan RS (komunikasi pribadi) untuk mempercepat penyembuhan luka. Mustafa et al. (2012) melaporkan ekstrak FSA dari ikan juga diperlukan untuk memenuhi kebutuhan serum albumin pada penanganan penyakit hypoalbumenia di rumah sakit yang semakin meningkat, sebagai alternatif dari HSA sintetik yang memiliki harga relatif mahal. Penelitian lainnya di bidang farmakologis juga menemukan bahwa ekstrak protein ikan gabus yang mengandung FSA maupun asam amino penting memiliki khasiat bioaktif untuk kesehatan kulit, antibakteri, antifungi, antinociceptive, dan penyeimbang agregasi trombosit (Hasnain et al. 2004; Jais, 2007).

Namun, saat ini ketersediaan ikan gabus di alam semakin menipis dengan indikasi kurangnya pasokan bahan baku yang diperlukan oleh UKM. Pengembangan budidaya ikan gabus masih dalam tahapan laboratorium, meskipun beberapa telah dikembangkan di lapangan dengan tingkat keberhasilan yang masih rendah. Proses reproduksi ikan gabus bergantung pada daya ekofisiologinya terhadap beberapa faktor lingkungan yang spesifik, seperti faktor fluktuasi perubahan ketinggian air (Bijaksana, 2012). Selain itu, penyediaan pakan juga menjadi tantangan pada upaya budidayanya, karena ikan gabus lebih menyukai pakan alamiah di alam (Victor \& Akpocha, 1992). Beberapa masalah ini yang menyebabkan budidaya ikan gabus masih belum berkembang dan dapat menjadi permasalahan bagi produksi nutraseutikal FSA yang berkesinambungan. Hal inilah yang mendasari dilaksanakannya penelitian ini. Riset bertujuan untuk mengetahui kandungan FSA pada beberapa jenis ikan air tawar yang telah dibudidayakan dengan baik, untuk mendapatkan bahan baku alternatif yang terjamin ketersediaannya secara berkelanjutan bagi produksi nutraseutikal berbasis FSA.

\section{BAHAN DAN METODE}

\section{Pengambilan Sampel dan Preservasi}

Tujuh belas jenis ikan perairan air tawar, dari ordo Perciformes, Anguilliformes, Cypriniformes, Osteoglossiformes, dan Siluriformes, yang telah dibudidayakan diambil dari Bogor (Cijeruk, Ciawi) dan Cianjur, Jawa Barat. Selain itu, ikan gabus yang umum dipergunakan dalam ekstraksi albumin (C. striata) juga diambil sebagai pembanding sehingga jumlah seluruh sampel menjadi 18 (Tabel 1). Identifikasi jenis dari setiap sampel dilakukan hingga tingkat spesies berdasarkan ciri morfologis yang dikemukakan oleh Kottelat et al. (1993). Setiap jenis ikan diambil 3-10 ekor ikan secara acak dengan bobot tubuh sekitar 150-500 g. Proses ekstraksi protein dilakukan segera setelah pengambilan sampel dilakukan. Sebanyak 25 $\mathrm{g}$ daging ikan dilarutkan dengan $75 \mathrm{ml}$ aquabides dan dihomogenisasi dengan menggunakan Ultra Turax homogeniser. Selanjutnya larutan ekstrak protein ikan tersebut dipreservasi dalam nitrogen cair hingga analisis albumin dilakukan di laboratorium.

\section{Analisis Kandungan Albumin}

Pada tahap awal, ekstrak sampel disentrifugasi dengan kecepatan 10.000 rpm selama 15 menit dengan menggunakan sentrifuse Beckman. Sebanyak $2 \mathrm{ml}$ ekstrak kemudian disaring dengan kertas saring berukuran 0,45 mikron. Selanjutnya, penentuan kadar kuantitatif albumin pada ekstrak hasil saringan dilakukan menggunakan High Performance Liquid Chromatography (HPLC) mengikuti Januar et al. (2015). HPLC yang digunakan adalah HPLC Shimadzu 2010A dengan instrumentasi Phenomenex Jupiter $(150 \times 20 \mathrm{~mm}) \mathrm{C} 5$ column dan menggunakan 
Tabel 1. Kode dan identifikasi taksonomis dari sampel ikan

Table 1. Code and taxonomic identification of fishes samples

\begin{tabular}{|c|c|c|c|c|c|}
\hline No & $\begin{array}{c}\text { Kode } \\
\text { Sampell } \\
\text { Sample } \\
\text { Code }\end{array}$ & Ordo/Order & Famili/Family & Spesies/Species & $\begin{array}{l}\text { Nama Lokall } \\
\text { Local Name }\end{array}$ \\
\hline 1 & $\mathrm{CS}^{*}$ & \multirow{8}{*}{ Perciformes } & \multirow{3}{*}{ Channidae } & Channa striata & Gabus \\
\hline 2 & $\mathrm{CM}$ & & & Channa micropeltes & Toman \\
\hline 3 & $\mathrm{CP}$ & & & Channa pleurophthalma & Gabus pleuro \\
\hline 4 & OM & & \multirow{2}{*}{ Cichlidae } & Oreochromis mosambicus & Mujair \\
\hline 5 & ON & & & Oreochromis niloticus & Nila \\
\hline 6 & HT & & Helostomatidae & Helostoma temminkii & Tambakan \\
\hline 7 & OG & & \multirow{2}{*}{ Osphronemidae } & Osphronemus goramy & Gurame \\
\hline 8 & TP & & & Trichopodus pectoralis & Sepat siam \\
\hline 9 & $A B$ & Anguilliformes & Anguilidae & Anguilla bicolor & Sidat \\
\hline 10 & $B G$ & \multirow{5}{*}{ Cypriniformes } & \multirow{5}{*}{ Cyprinidae } & Barbonymus gonionotus & Tawes \\
\hline 11 & $\mathrm{CC}$ & & & Cyprinus carpio & Mas \\
\hline 12 & $\mathrm{HM}$ & & & Hypophthalmichthys molitrix & Mola \\
\hline 13 & NS & & & Neolisochilus soro & Torsoro \\
\hline 14 & ov & & & Osteochilus vittatus & Nilem \\
\hline 15 & NC & Osteoglossiformes & Notopteridae & Notopterus chitala & Belida \\
\hline 16 & $\mathrm{HN}$ & \multirow{3}{*}{ Siluriformes } & Bagriidae & Hemibagrus nemurus & Baung \\
\hline 17 & $\mathrm{CB}$ & & Clariidae & Clarias batrachus & Lele \\
\hline 18 & $\mathrm{PH}$ & & Pangasiidae & $\begin{array}{l}\text { Pangasianodon } \\
\text { hypophthalmus }\end{array}$ & Patin \\
\hline
\end{tabular}

detektor PDA (Photo Diode Array) pada panjang gelombang $280 \mathrm{~nm}$. Fase gerak HPLC adalah menggunakan $0,1 \%$ asam trifluoroasetat dalam air (pelarut $\mathrm{A}$ ) dan $0,1 \%$ asam trifluoroasetat dalam pelarut asetonitril (pelarut B). Fase gerak mengelusi sampel secara gradasi dari $90 \%$ hingga $10 \%$ pelarut A selama 30 menit dengan kecepatan alir fase gerak $0,2 \mathrm{ml} / \mathrm{menit}$ dan volume injeksi 20 ul. Penghitungan kadar albumin dilakukan berdasarkan perbandingan luas area puncak albumin sampel terhadap standar Bovine Serum Albumin (BSA) dari Biogen. Plot antara konsentrasi standar terhadap luas area puncaknya di kromatogram HPLC dibuat sebelum pelaksanaan analisis sampel, dengan seri konsentrasi 250,500 , 1000, dan 2000 ppm.

\section{Profil Asam Amino}

Pengujian asam amino dibatasi terhadap dua jenis ikan, yaitu ikan yang memiliki kadar FSA tertinggi dan ikan gabus (C. striata) sebagai pembanding. Ekstrak air dari sampel dikeringkan dengan menggunakan instrumentasi freeze dryer. Selanjutnya, sampel ekstrak air kering (tiga ulangan) tersebut di hidrolisis bersasarkan metode Csapo et al. (2008). Sampel ditimbang sebesar $20 \mathrm{mg}$ dalam botol sampel, ditambahkan $1 \mathrm{ml} \mathrm{HCl} 6 \mathrm{~N}$, selanjutnya dipanaskan secara konstan selama 60 menit pada suhu $180^{\circ} \mathrm{C}$ di Microwave. $100 \mu \mathrm{l}$ sampel hasil hidrolisis dipreparasi mempergunakan testing kit EZ-Faast ${ }^{\mathrm{tm}}$ GC-FID hydrolyzed amino acids analysis kit - Phenomenex (KG0-7167). Komposisi asam amino dari sampel selanjutnya di analisis menggunakan Gas Chromatography - Flame Ionization Detector (GC-FID) dengan standar 24 asam amino essensial dan nonesensial dari Phenomenex (AG0-7184).

\section{HASIL DAN BAHASAN}

Pengujian HPLC terhadap standar BSA mendapatkan nilai determinasi sebesar 0,9985 (Gambar 1). Aplikasi instrumentasi fasa balik HPLC merupakan teknik yang baik dan sensitif pada penentuan kadar berbagai jenis protein (Kovyrshina \& Rudneva, 2012). Determinasi antara standar BSA 


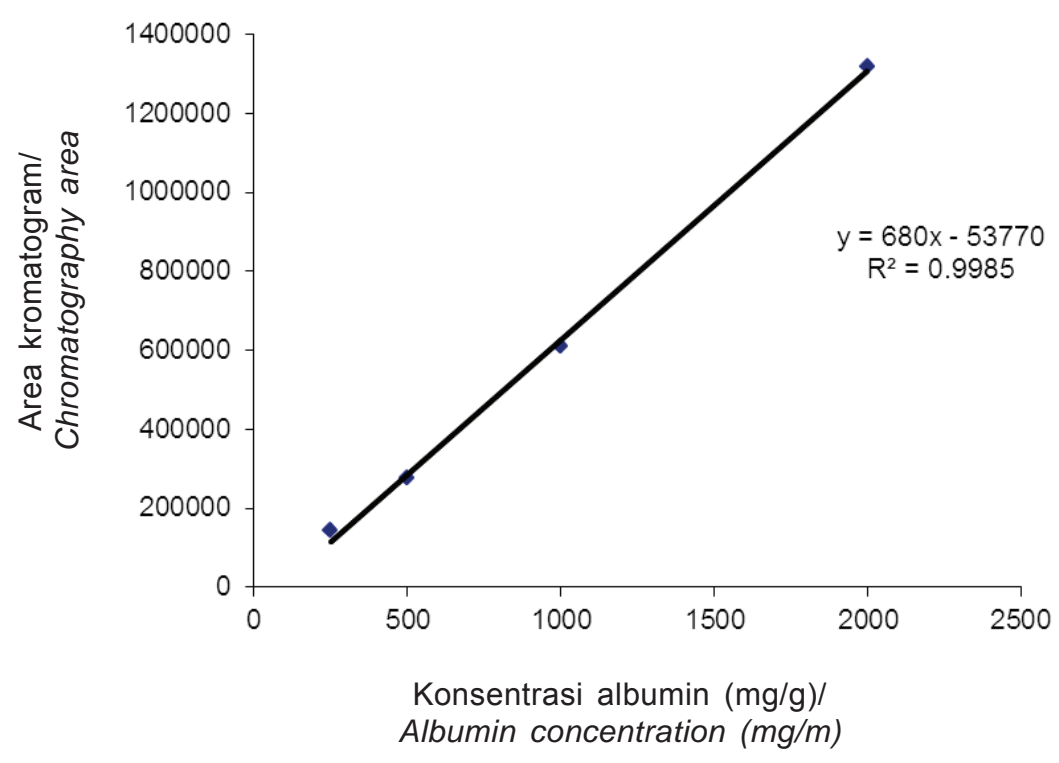

Gambar 1. Kurva standar Bovise Serum Albumin (BSA). Figure 1. Standard curve Bovine Serum Albumin (BSA).

dan luas areanya yang mendekati 1 menunjukkan bahwa sensitivitas pengujian adalah baik, dengan detektor instrumentasi yang mampu mengkorelasikan secara linear kenaikan konsentrasi analit.

Hasil pengujian ekstrak air sampel ikan menunjukkan kadar FSA yang berada pada kisaran 36-215 mg/g, dengan FSA pada sampel ikan gabus (C. striata) pembanding sebesar $107,28 \mathrm{mg} / \mathrm{g}$ (Gambar 2). Secara umum, konsentrasi FSA dari keseluruhan sampel ikan, yaitu Perciformes (delapan jenis ikan), Anguiliformes (satu jenis ikan), Cypriniformes (lima jenis ikan), Osteoglossiformes (satu jenis ikan) dan Siluriformes (tiga jenis ikan), terlihat bervariasi dan tidak menunjukkan pola tertentu. Konsentrasi FSA memiliki keragaman yang tinggi meskipun masih terdapat dalam satu kelompok famili ikan. Pada satu kelompok ikan famili Channidae, ikan gabus (C. striata) yang diperoleh dari alam memiliki kadar FSA sebesar 107,28 \pm 3,2 mg/g, sementara gabus pleuro (C. pleurophthalma) dan toman (C. micropeltes) memiliki kadar FSA berturut-turut sebesar 46,68 $\pm 7,28 \mathrm{mg} / \mathrm{g}$, dan 57,99 $\pm 7,84 \mathrm{mg} / \mathrm{g}$. Penelaahan terhadap pustaka juga menemukan kadar yang bervariasi dari spesies pada famili ini. Carvallo (1998) dalam Nugroho (2013) melaporkan bahwa kadar albumin ikan gabus (C. striata), dan ikan toman (C. micropeltes) masing-masing sebesar $13,327 \mathrm{mg} / \mathrm{g}$ dan $11,880 \mathrm{mg} / \mathrm{g}$. Sementara hasil penelitian Firlianty et al. (2013) menunjukkan bahwa filtrat FSA ikan gabus (C. striata) dari perairan Kalimantan Tengah mencapai $67,8 \mathrm{mg} / \mathrm{g}$, gabus toman (C. micropeltes) sebesar
$89,3 \mathrm{mg} / \mathrm{g}$, dan gabus pleuro (C. pleurophthalma) sebesar $89,6 \mathrm{mg} / \mathrm{g}$.

Variasi kandungan protein seperti FSA dan komponen lain dalam daging ikan tergantung pada jenis ikan, ukuran, tingkat pemberian pakan, keberadaan dan kualitas pakan, serta kandungan energi yang dapat dicerna pada pakan (Niwa et al., 2007). Irianto \& Susilo (2007) juga melaporkan komposisi kimia ikan dapat bervariasi tergantung kepada spesies, umur, jenis kelamin, ketersediaan pakan di air, habitat dan kondisi lingkungan. Selainitu, kadar FSA dalam ikan dipengaruhi juga oleh faktor genetik (Hasnain et al., 2004). Beberapa spesies ikan dari kelompok bertulang rawan (Elasmobranchii) tidak mengandung FSA dalam tubuhnya, sedangkan beberapa golongan teleostei (bertulang sejati) memiliki kadar FSA yang sangat rendah, dan beberapa jenis ikan memiliki FSA spesifik atau yang disebut sebagai protein seperti albumin (Hasnain et al., 2004).

Selain itu, penelitian ini juga mendapatkan jenisjenis ikan yang memiliki kadar FSA yang hampir sama dan lebih besar dari ikan gabus. Ikan-ikan ini adalah ikan tambakan (Helostoma temminkii), tosoro (Neolisochillus soro), lele (Clarias batrachus), dan gurame (Osphronemus goramy), dengan kadar masing-masing adalah 118,13 \pm 7,98 mg, 102,67 \pm $2,99 \mathrm{mg} / \mathrm{g}, 103,37 \pm 1,53 \mathrm{mg} / \mathrm{g}$, dan $215,57 \pm 52,84$ $\mathrm{mg} / \mathrm{g}$. Kadar albumin yang tinggi pada ikan gurame ini sebanding dengan kandungan total proteinnya, yaitu sekitar 18,71-20,67\%, sehingga termasuk dalam golongan ikan yang memiliki kadar protein tinggi 


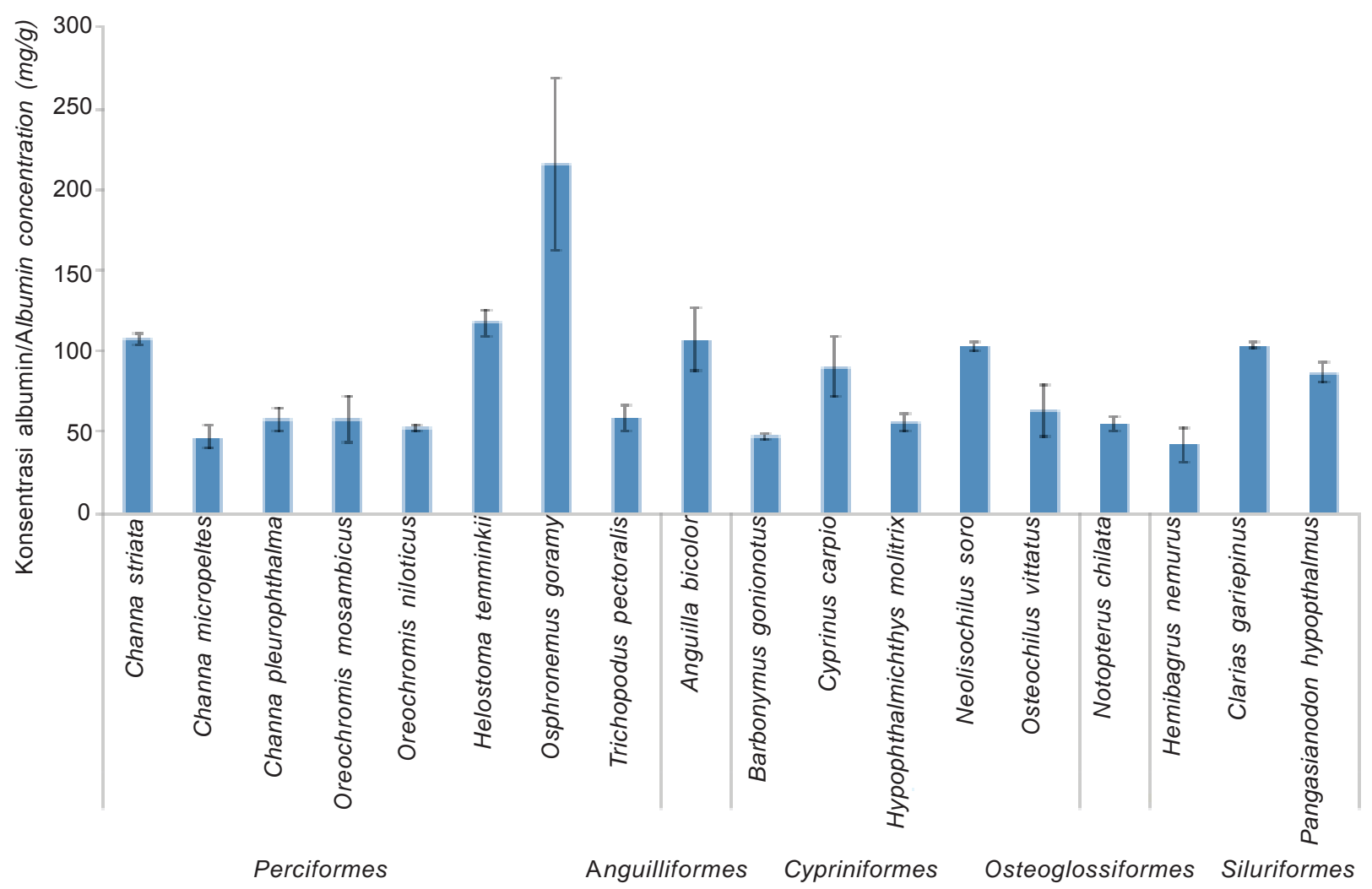

Gambar 2. Konsentrasi albumin ekstrak beberapa ikan air tawar dengan garis kesalahan adalah SD dan $\mathrm{n}=3$.

Figure 2. Concentration of albumin extract some freshwater fishwith error bars representing SD and $n=3$.

(Nianda, 2008). Deviasi yang tinggi pada FSA ikan gurame menunjukkan bahwa keselarasan faktor lingkungan dan umur panen menjadi hal yang penting untuk menjaga deviasi yang rendah dari rendemen FSA dalam ekstrak air ikan ini.

Keberadaan FSA yang lebih tinggi pada ikan gurame diduga memiliki peran fisologis, terkait fungsinya dalam tubuh ikan sebagai transport protein dalam plasma. FSA dalam plasma ikan telah dikonfirmasi berdasarkan massa molekul, sifat pengikatan asam lemak, dan mobilitas elektroforesis (Hoar et al. 1992). Berdasarkan massanya, FSA dalam plasma pada jenis ikan agnatha (tidak berahang), elasmobarnch (bertulang rawan seperti hiu, pari), dan teleostei (bertulang sejati) memiliki berat molekur mirip dengan serum albumin manusia (68-70 kDa). Kemudian, berdasarkan sifat pengikatan terhadap asam lemak, FSA pada ikan jenis agnatha dan teleostei mengikat asam lemak (palmitat dan oelate) dan bilirubin. Namun pada elasmobranchi, terdapat protein FSA yang tidak mengikat asam lemak melainkan hanya mengikat bilirubin, hal ini terlihat dengan rendahnya tingkat asam lemak plasma bebas yang ditemukan di spesies ini. Fungsinya yang penting bagi pengikatan lemak tersebut dapat diduga sebagai penyebab tingginya kadar FSA di jenis ikan agnatha dan teleostei. Ikan teleostei (ikan bertulang sejati seperti gurame, lele) mempunyai konsentrasi FSA sekitar 25-50\% dari total protein dan ikan jenis agnatha (ikan tak berahang seperti belut) memiliki FSA berkisar 15\% dari total protein (Hoar et al., 1992).

Analisis lebih lanjut mengenai komposisi asam amino ekstrak air ikan gurame, yang memiliki konsentrasi FSA tertinggi dari penelitian ini, jika dibandingkan dengan ekstrak air ikan gabus menunjukkan bahwa asam amino dalam ekstrak air ikan gabus memiliki komposisi lebih beragam dengan konsentasi yang lebih tinggi dari ekstrak air ikan gurame. Ikan gabus memiliki asam amino esensial yang lebih tinggi selain asam amino tryptophan dan metionin dibandingkan ikan gurame, dengan jenis asam amino essensial dominan leusin, lisin, dan fenilalanin (Gambar 3). Selain itu, kandungan asam amino non esensial pada ikan gabus juga lebih tinggi dibanding pada ikan gurame, selain $\alpha$-aminoadipic acid dan $\alpha$-aminoisobutirat, dengan jenis asam amino 


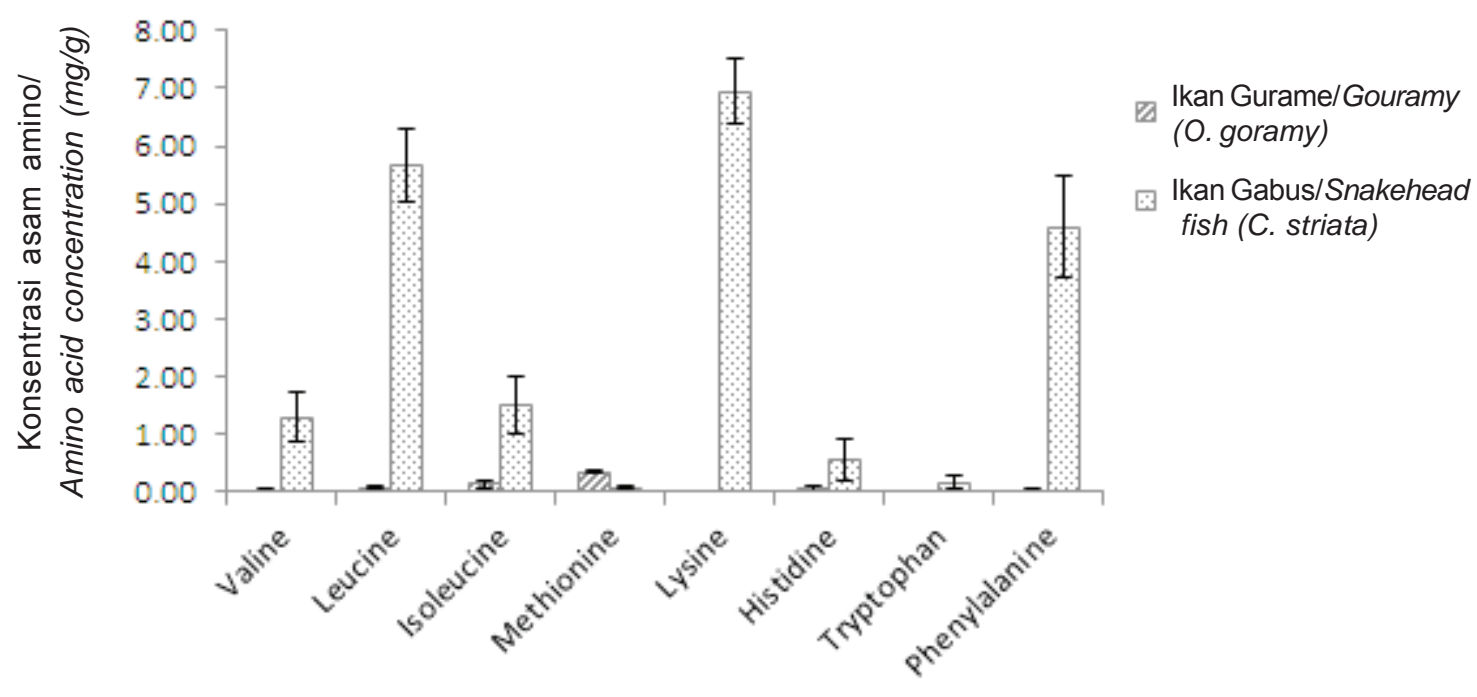

Asam amino esensial/Essensial amino acids

Gambar 3. Profil asam amino esensial ikan gabus (C. striata) dan gurame (O. goramy) dengan garis kesalahan adalan $\mathrm{SD}$ dan $\mathrm{n}=3$.

Figure 3. Essential amino acid profile of snakehead fish (C. striata) and giant gouramy (O. goramy) with error bars representing SD and $n=3$.

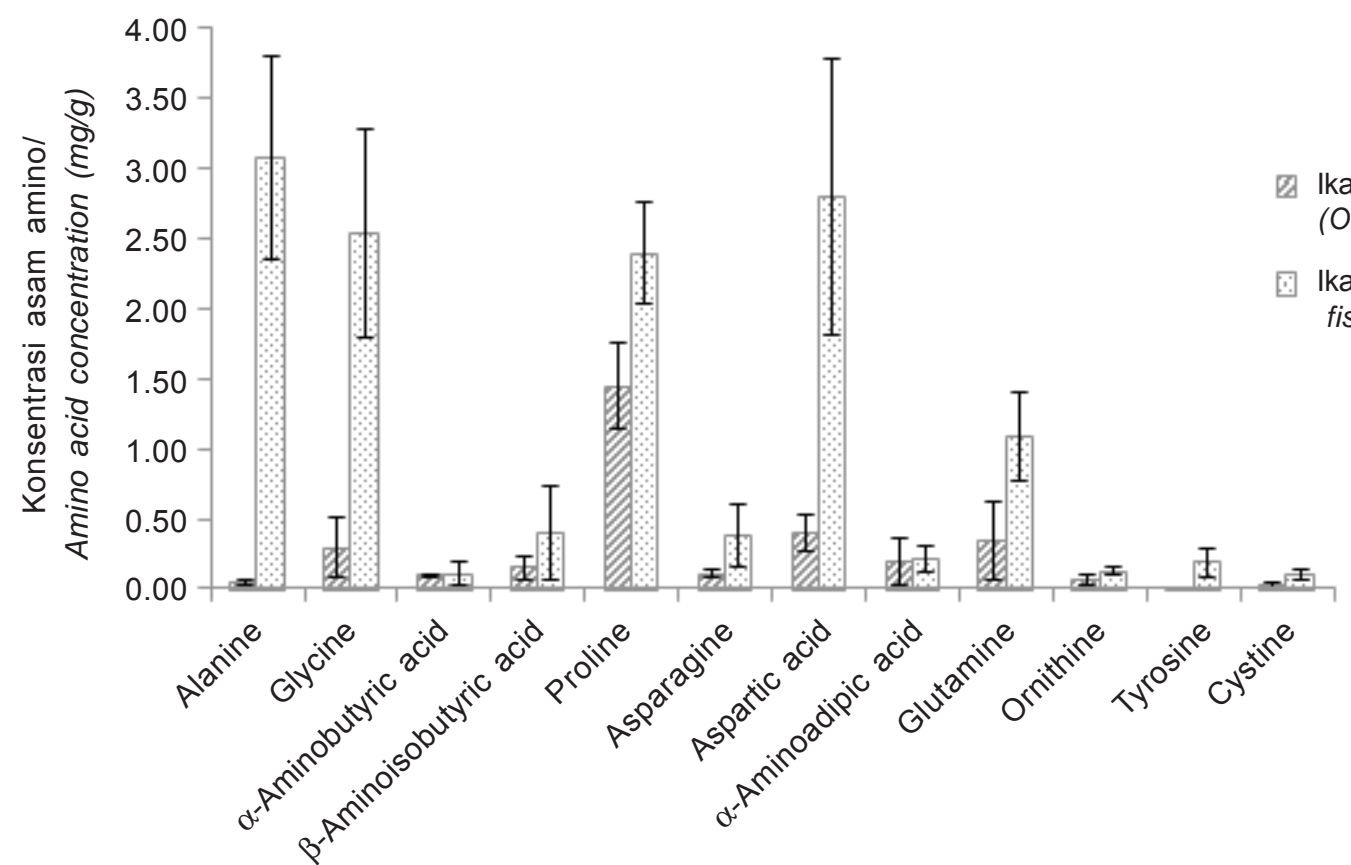

Asam amino non esensial/Non essensial amino acids

Gambar 4. Profil asam amino non esensial ikan gabus (C. striata) dan gurame (O. goramy) dengan garis kesalahan adalan SD dan $\mathrm{n}=3$.

Figure 4. Non essential amino acid profile of snakehead fish (C. striata) and giant gouramy (O. goramy) with error bars representing $S D$ and $n=3$. 
non esensial dominan adalah alanine, glisin, prolin, dan asam aspartat (Gambar 4). Kadar asam amino yang terekstrak pada pelarut air ini relatif jauh lebih rendah jika dibandingkan dengan telaah referensi kadar asam amino dari daging ikan. Kadar asam amino non esensial pada ikan gabus yang dipanen dari daerah Pontian, Malaysia memiliki glisin 124,9 mg/g, asam aspartat 109,0 mg/g dan alanin 107,7 mg/g (Zakaria et al., 2007). Hal ini menunjukkan dugaan adanya kandungan protein tak larut air yang tinggi di dalam ikan. Selain itu, komposisi asam amino juga dapat bervariasi. Ghassem et al. (2011) mengungkapkan bahwa protein dan asam amino esensial dalam ikan C. striata dari perairan di sekitar Malaysia lebih beragam dan memiliki konsentrasi yang lebih tinggi dibandingkan dengan ikan perairan daratan lainnya. Penelitian yang dilakukan oleh Shafri \& Manan (2012) menyebutkan bahwa ekstrak ikan gabus yang berasal dari perairan sekitar Peninsular, Malaysia mengandung asam amino non esensial yang didominasi jenis glisin, asam glutamik dan asam aspartat. Meskipun demikian, kadar asam amino antar ikan C. striata ini berbeda antara lokasi satu dengan lainnya di mana panen ikan tersebut dilakukan. Dahlan et al. (2010) melaporkan bahwa dalam satu spesies ikan yang hidup pada lingkungan yang berbeda akan membentuk profil asam amino dan komposisi yang berbeda.

Keberadaan asam-asam amino yang bervariasi lebih tinggi dalam ekstrak air ikan gabus dibandingkan dengan ekstrak air ikan gurame menunjukkan potensinya sebagai produk hidrolisat protein. Asam amino telah diketahui memiliki fungsi bioaktif penting. Asam amino esensial seperti lisin dan leusin dapat berperan dalam kontrol kolesterol, membantu perbaikan jaringan tubuh, dan juga transduksi sinyal intraseluler (Layman, 2002; Ovie \& Eze, 2013; Sundari et al., 2014). Selain itu, asam-asam amino non esensial seperti glisin juga dapat berperan dalam penyembuhan luka, pertumbuhan jaringan baru, pengurangan rasa nyeri, dan memiliki peran sebagai neurotransmiter pada simpul syaraf (Huang et al., 2001; Thornton et al., 2002 dalam Zuraini et al., 2006; Chyun \& Griminger, 1984 dalam Zakaria et al., 2007; Zakaria et al., 2007; Purwaningsih, 2012; Shafri \& Manan, 2012). Namun, tingginya asam amino dan rendahnya kadar FSA di ekstrak air ikan gabus mengindikasikan keberadaan protein-protein jenis lain, selain FSA, yang lebih tinggi dibandingkan dengan ekstrak air dari ikan gurame. Kandungan asam amino yang lebih rendah serta kadar FSA yang lebih tinggi dalam ekstrak air ikan gurame menunjukkan bahwa FSA dalam ekstrak air ikan ini lebih murni dibandingkan dengan ekstrak air yang bersumber dari ikan gabus. Oleh karena itulah, ikan gurame memiliki potensi yang sangat tinggi untuk dikembangkan sebagai bahan baku alternatif untuk produksi nutraseutikal berbasis FSA.

\section{KESIMPULAN}

Ikan gurame (O. gouramy) budidaya memiliki kadar FSA yang lebih tinggi dibanding ikan gabus (C. striata). Penelaahan lebih lanjut mengenai komposisi asam amino memperlihatkan bahwa ekstrak air dari ikan gurame memiliki kandungan FSA yang lebih murni dibandingkan dengan eksrak air ikan gabus. Oleh karena itu, ikan gurame memiliki potensi yang tinggi sebagai bahan baku alternatif selain ikan gabus dalam pengembangan produksi nutraseutika berbasis FSA. Pada penerapannya, keselarasan kondisi lingkungan dan juga umur panen dari ikan gurame menjadi hal yang sangat penting untuk menjaga deviasi yang rendah dari rendemen kadar FSA yang dapat diekstrak dari ikan ini.

\section{UCAPAN TERIMA KASIH}

Terima kasih disampaikan kepada Sri Iswani yang telah membantu dalam analisis dan tim penelitian biopotensi beberapa ikan unik Indonesia.

\section{DAFTAR PUSTAKA}

Ahmad Z, Somchit, M.N., Mohamad Hasan, S., Goh, Y.M., Abdul Kadir, A., Zakaria, M.S., Mat Jais, A.M., Rajion, M.A., Zakaria, Z.A., \& Somchit, N. (2005). Fatty acid and amino acid composition of three local Malaysian Channa spp. Fish. Food Chem, 97(4), 674-678.

Andreeva A.M. (2011). Mechanisms of the plurality of Scorpaena porcus L. serum albumin. Open Journal of Marine Science, 1, 31-35.

Bijaksana, U. (2012). Dosmestikasi ikan gabus, Channa striata Blkr, upaya optimalisasi perairan rawa di Provinsi Kalimantan Selatan. Jurnal Lahan Suboptimal, 1(1), 92-101.

Baker, M.E. (2002) Albumin, steroid hormones and the origin of vertebrates. Journal of Endocrinology, 175, 121-127.

Carvallo, Y. N. (1998). Study Profit Asam Amino, Albumin, Mineral Zn pada Ikan Gabus (Ophiocephalus sriatus) dan Ikan Tomang (Ophiocephalus Micropeltus). Fakultas Perikanan. Universitas Brawijaya, Malang. pp. 28-30.

Csapo J., Kiss-Csapo, ZS., Albert, Cs., \& Loki, K. (2008). Hydrolysis of proteins performed at high temperatures and for short times with reduced racemization, in order to determine the enantiomers of D- and L-amino acids. Acta Univ. Sapientiae, Alimentaria, 1, 31-48

Dahlan-Daud, C.K., Mat Jais, A.M.Z., Ahmad, A.M., Akim, D., \& Adam, A. (2010). Amino and fatty acid composition in Haruan traditional extract (HTE). 
Boletin Latinoamericano y del Caribe de Plantas Medicinales y Aromaticas, 9(5), 414-429.

De Smet, H., Blust, R. \& Moens, L. (1998) Absence of albumin in the plasma of the common carp Cyprinus carpio: binding of fatty acids to high density lipoprotein. Fish Physiol. and Biochem, 19, 71-81.

Firlianty, Suprayitno, E., Nursyam, H., Hardoko, \& Mustafa, A. (2013). Chemical composition and amino acid profile of channidae collected from central Kalimantan, Indonesia. International Journal of Science and Technology (IJSTE), 2(4), 25-29.

Gam, L.H., Leow, C.Y., \& Baie, S. (2006). Proteomic analysis of snakehead fish (Channa striatus) muscle tissue. Mal J of Biochem and Molec Biol., 14: 25-32.

Ghassem, M., Arihara, K., Babji, A.S., Said, M., \& Ibrahim, S. (2011). Purification and identification of ACE inhibitory peptides from Haruan (Channa striatus) myofibrillar protein hydrolysate using HPLC-ESI-TOF MS/MS. Food Chemistry, 129, 1770-1777.

Hammer, O., Harper, D.A.T., \& Ryan, P.D. (2001). Past: Palaentological Statistics Software package for education and data analysis. Palaentological Electronics, 4(1), 9.

Hasnain, A., Ahmad, R., Jabeen, M., \& Khan, M.M. (2004) Biochemical characterization of a protein of albumin multigene family from serum of African catfish Clarias gariepinus Bloch. Indian J. Biochem. Biophys, 41, 148-153.

Hoar, W.S., Randall, D.J. \& Farrel, A.P. (1992). Fish Fishiology: The Cardiovascular System, Volume VII, Part B. Academic press inc.

Huang, S.M., Bisogno, T., \& Petros, T.J. (2001). Identification of a new class of molecules the arachidonyl amino acids, and characterization of one member that inhibits pain. Journal Biological Chemistry, 276, 42639-42644.

Irianto H.E \& Indroyono S., (2007). Dukungan Teknologi Penyediaan Produk Pangan. Dipaparkan dalam Seminar Nasional Hari Pangan Sedunia XVII.

Januar, H.I., Nurrahmi D. F., Dewi, S.Z., Bramandito, A., \& Wright, A.D. (2015). Concentration of fish serum albumin (FSA) in the aqueous extract of Indonesian Perciformes fishes' muscle tissue. Natural Product Research. http://dx.doi.org/10.1080/14786419.2014. 1003298.

Jais Mat, A.M. (2007). Pharmacognosy and pharmacology of Haruan (Channa striatus), a medicinal fish with wound healing properties. Review. Boletín Latinoamericano y del Caribe de Plantas Medicinales Aromáticas, 6(3): 52-60.

Kottelat, M., Whitten, A.J., Kartikasari, S.N., \& Wirjoatmodjo, S. (1993). Ikan Air Tawar Indonesia Bagian Barat dan Sulawesi. Edisi dwibahasa. Periplus editions.
Kovyrshina, T.B. \& Rudneva, II. (2012). Comparative study of serum albumin level in round goby Neogobius melanostomus form Black Sea and Azov Sea. Int. J. Adv. Biol. Res, 2, 203-208.

Layman. D.K. (2002). Role of leucine in protein metabolism during exercise and recovery. Can. J. Appl. Physiol, 27(6), 646-662.

Mustafa, A., Aris Widodo, M., \& Kristianto, Y. (2012). Albumin and zinc content of snakehead fish (Channa striata) extract and its role in health. IEESE International Journal of Science and Technology (IJSTE). 1(2), 1-8.

Niwa, Y., Irma, M.H., Rina, H., \& Yoyo, W. (2007). Nutrisi dan bahan pakan ikan budidaya. Balai Budidaya Air Tawar, Jambi.

Nianda T. (2008). Komposisi protein dan asam amino daging ikan gurame (Osphronemus gouramy) pada berbagai umur panen. $71 \mathrm{p}$.

Nugroho, M. (2013). Uji biologis ekstrak kasar dan isolat albumin ikan gabus (Ophiocephalus striatus) terhadap berat badan dan kadar serum albumin tikus mencit. Jurnal Saintek Perikanan, 9(1), 49-54.

Ovie, . S.O \& S.S. Eze. (2013). Lysine requirement and its effect on the body composition of Oreochromis niloticus fingerlings. Journal of Fisheries and Aquatic Science, 8(1), 94-100.

Purwaningsih, S. (2012). Antioksidan dan komposisi kimia keong matah merah (Cerithidea obtusa). IImu Kelautan, 17(1), 39-48.

Shafri, M.M.A. \& Manan, M.J. (2012). Therapeutic potential of the Haruan (Channa striatus): from food to medicinal uses. Mal. J. Nutr, 18(1),125-136.

Sundari, Zuprizal, Tri Y, \& Ronny M. (2014). Effect of nanocapsule level on broiler performance and fat deposition. International Journal of Poultry Science, 13(1), 31-35.

Victor, R., \& Akpocha, B.O. (1992). The biology of Snakehead, Channa obscura (Gunther), in a Nigerian pond under monoculture. Aquaculture, 101(1), 1724.

Witte \& Barbul, A. (2002). Role of nitric oxide in wound repair. Am J Surg, 183(4), 406-412.

Zuraini, A., Somchit, M. N., Solihah, M. H., Goh, Y. M., Arifah, A. K., Zakaria, M. S., Somchit, N., Rajion, M. A., Zakaria, Z. A. \& Mat Jais, A. M. (2006) Fatty acid and amino acid composition of three local Malaysian Channa spp. Fish. Food Chemistry, 97(4), 674-678.

Zakaria, Z.A., AM Mat Jais, Goh, Y.M., Sulaiman, M.R. \& Somchit, M.N. (2007). Amino acid and fatty acid composition of an aqueous extract of Channa striatus (haruan) that exhibits antinociceptive activity. Clinical and Experimental Pharmacology and Physiology, 34, 198-204. 